\title{
PROBLEMS ABOUT PATENT RIGHTS
}

\author{
M REZA FAHLEPI \\ Fakultas Komputer \\ muhammadrezapahlevi.student@umitra.ac.id
}

\begin{abstract}
Patent is an exclusive right granted by the State to the inventor of the results of his invention in the field of technology, which for a certain period of time carries out his own invasion or gives his consent to other parties to implement it. (Law 14 of 2001, Ps. 1, v. 1). Meanwhile, the meaning of the Invention and Inventor (contained in the above definition, also according to the law, is):

- Invention is an Inventor idea that is poured into a specific problem-solving activity in the field of technology can be a product or process, or an improvement or development of a product or process. (Law 14 of 2001, Ps. 1, v. 2)

- Inventor is a person who or some person who jointly carries out an idea poured into an activity that produces an invention. (Law 14 of 2001, ps. 1, v. 3)

The word patent comes from the English patent, which originally came from the word patere which means opening up (for public examination), and also comes from the term letter patent, which is a decree issued by the kingdom that gives exclusive rights to individuals and certain business actors. From the definition of the word patent itself, the patent concept encourages inventors to open knowledge for the betterment of society and instead, inventor gets exclusive rights for a certain period. Given that the patent does not regulate who has to do a patented invention, the patent system is not considered a monopoly right.

Explanation of the Patents and Systems Applied in Indonesia Regarding the Application for Patent Rights
\end{abstract}




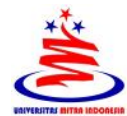




\section{A. INTRODUCTION}

\section{DEFINITION}

The definition of patent has been regulated in Law No. 14 of 2001 concerning patents. In this law, it regulates patent conditions, the validity period of patents, the rights and obligations of inventors as inventors of inventions, procedures for applying for patents, announcements and substantive examinations etc. With the existence of this law, it is expected that there will be protection from intellectuals from Indonesian sons and daughters. The object of patent rights is invention which can be practically used in the industrial sector. That is why Patent Rights are included in the type of industrial property rights, which distinguish them from Copyright. The invention that can be granted a patent is only a new invention in the field of technology. The invention is intended, can be in the form of technology that exists in a particular product or the method used in the process of producing certain products. So that patents can be given to products and production process technology.

\section{Patent 1 Issue 1 (Microsoft vs Google)}

Microsoft vs. Google originated from Google's demands to Microsoft for compensation for a sum of money for violating Google's patents. Microsoft is accused of using Motorola's patented technology on its Xbox and Surface tablet. One Motorola expert gave a testimony to Seattle Court, United States that Microsoft will get a profit of US \$ 94 billion from the sale of its products until 2017. Motorola demands annual patent royalties of US $\$ 4$ billion for wireless and video technology that Microsoft uses in Xbox and Surfece tablet. But Microsoft feels they only need to pay a license fee of US \$ 1 million per year. If this is approved by the judge, Motorola will lose its bargaining position in Google licensing issues with its rivals.

The Motorola mobile company that Google bought in May when it was threatened with bankruptcy was felt to still have strength in terms of products and patents. Therefore, Google is willing to buy this company for US \$ 12.5M. Of course Google does not want to let go of the rights that Motorola has in the hands of its competitors. This 
Google vs. Microsoft trial will take place in one week to check how much royalty Microsoft has to pay to Google.

Settlement

The U.S International Trade Commission administration judge has given his verdict on Friday, 25/03/2013 related to the problem of Microsoft vs Motorola XBOX. The verdict is that the Judge did not find a violation related to the patent issue reported by Motorola. More fully, Hakin David P. Shaw said that the $\mathrm{XBOX}$ did not violate patents on section 337 of the Traffic Act in 1930.

\section{B. CONCLUSION}

The U.S International Trade Commission administration judge has given his verdict on Friday, 25/03/2013 related to the problem of Microsoft vs Motorola XBOX. The verdict is that the Judge did not find a violation related to the patent issue reported by Motorola. More complete, Hakin David P. Shaw said that XBOX tidak melangar hak paten terhadap seksi 337 of the Traffic Act tahun 1930.

\section{ACKNOWLEDGEMENT} University Of Indonesia University Of Mitra Indonesia Telkom University University Of Mellbourne Saitama University 
[1] A. S. Putra And O. M. Febriani, "Knowledge Management Online Application In Pdam Lampung Province," In 
Prosiding International

Conference On Information

Technology And Business

(Icitb), 2018, Pp. 181-187.

[2] A. S. Putra, O. M. Febriani, And

B. Bachry, "Implementasi

Genetic Fuzzy System Untuk

Mengidentifikasi Hasil Curian

E. REFERENCE (Based APA)

Kendaraan Bermotor Di Polda

Lampung," J. Sist. Inf. Dan

Manaj. Basis Data, Vol. 1, No.

1, Pp. 21-30, 2018.

[3] O. M. Febriani And A. S. Putra, "Sistem Informasi Monitoring Inventori Barang Pada Balai Riset Standardisasi Industri Bandar Lampung," J. Inform.,

Vol. 13, No. 1, Pp. 90-98, 2014.

[4] Putra, Arie Setya. "2018 Artikel Struktur Data, Audit Dan Jaringan Komputer." (2018).

[5] Putra, A. S. (2018, July 17). Paperplain Fundamental Create Application With Borland Delphi 7.0 University Of Mitra Indonesia. Retrieved From Osf.Io/Pbrn9.

Putra, A. S., Aryanti, D. R., \& Hartati, I. (2018, November). Metode SAW (Simple Additive Weighting) sebagai Sistem Pendukung Keputusan Guru Berprestasi (Studi Kasus: SMK Global Surya). In Prosiding Seminar Nasional Darmajaya (Vol. 1, No. 1, pp. 85-97).

Sari, D. P., Febriani, O. M., \& Putra, A. S. (2018, November). Perancangan Sistem Informasi SDM Berprestasi pada SD Global Surya. In Prosiding Seminar Nasional Darmajaya (Vol. 1, No. 1, pp. 289-294).

Putra, A. S. (2018). Paperplain: Execution Fundamental Create Application With Borland Delphi 7.0 University Of Mitra Indonesia. 
Putra, A. S., Sukri, H., \& Zuhri, K. Sistem Monitoring Realtime Jaringan Irigasi Desa (JIDES) Dengan Konsep Jaringan Sensor Nirkabel. IJEIS (Indonesian Journal of Electronics and Instrumentation Systems), 8(2), 221232.

Darmawan, A., Yuliawati, D., Marcella, O., \& Firmandala, R. (2016). Sistem Absensi dan Pelaporan Berbasis Fingerprint dan SMS Gateway. EXPLORE, 7(1).

Febriani, O. M., Wahyuni, T., \& Yusuf, S. (2017). DESIGN OF WEBSITEBASED INFORMATION SYSTEM FOR EDOCUMENT ADMINISTRASI IN THE COMMUNITY SERVICE UNIT (A Case Study at Rajabasa District). INTERNATIONAL JOURNAL OF COMPUTERS \& TECHNOLOGY, 16(7), 7010-7020.

Febriani, O. M., \& Wahyuni, T. (2017, October). PERANCANGAN SISTEM E-DOCUMENT ADMINISTRASI LOGBOOK PENELITIAN PADA
UNIT LAYANAN DI BANDAR LAMPUNG. In Prosiding Seminar Nasional Darmajaya (Vol. 1, No. 1, pp. 187-194).

Febriani, O. M., \& Permadi, A. B. (2017). Implementasi Sistem Aplikasi Data Bimbingan dan Pelanggaran Siswa pada Sekolah Menengah Atas di Lampung Tengah dengan Metode Analisis dan Desain Sistem Terdistribusi (SSAD). EXPERT, 7(1).

Febriani, O. M., \& Ambarwati, L. (2015). PERANCANGAN APLIKASI PENGOLAHAN DATA PENJUALAN UKM KELANTING KHAS TELO DESA SIDOHARJO KECAMATAN JATI AGUNG KABUPATEN LAMPUNG SELATAN. Jurnal Teknologi Informasi dan Bisnis Pengabdian Masyarakat Darmajaya, 1(1), 77-95.

Febriani, O. M. (2015). Rancang Bangun Aplikasi Ecommercemenggunakan Freewebstore pada UKM Kelanting di Desa 


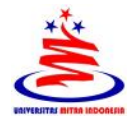

Sidoharjo Lampung Selatan. Prosiding

Sembistek 2014, 1(02), 446-458. 